\title{
Follow the Light: Adriaan Reland (1676-1718) on Muhammad
}

\author{
Christian Lange
}

At the hands of the European Republic of Arabic Letters (ca. 1650-1750), ${ }^{1}$ the Western perspective on Muhammad underwent a profound transformation. ${ }^{2}$ The Utrecht professor of Oriental languages Adriaan Reland (1676-1718), who occupied an exalted position in the network of European Arabists around 1700, contributed lastingly to a new and better understanding of the prophet of Islam, to the extent that the German philosopher Gotthold Ephraim Lessing (1729-1781), writing in 1754, could state that 'we did not possess genuine knowledge ... before the works of Reland and Sale, from which we have learned especially that Mahomet was no senseless impostor and that his religion is not merely a poorly woven fabric of inconsistencies and distortions. ${ }^{3}$

George Sale (1697-1736), the first translator of the Qur'ān from Arabic to English and author of the influential 'Preliminary Discourse' (1734), is regularly given credit for facilitating a balanced approach to Islam among the educated European public. Reland, by contrast, has flown somewhat under the radar of historians of Islamic scholarship in the West. ${ }^{4}$ How, then, did Reland

1 I borrow this term from Bevilacqua, Republic of Arabic Letters.

2 The research for, and writing of, this essay was supported by the ERC Consolidator Grant "The senses of Islam" (project no. 724951). I wish to thank Bart Jaski, Henk van Rinsum and Arnoud Vrolijk for providing valuable feedback on a draft of this essay.

3 Lessing, 'Rettung des Hieronymus Cardanus', p. 153. All translations, unless otherwise indicated, are mine.

4 In his landmark study, Johann Fück mentions Reland only in passing. See Fück, Die arabischen Studien, pp. 102-103. Norman Daniel, in another standard account, is highly positive about Reland, but extremely brief (he devotes no more than half a paragraph to him). See Daniel, Islam and the West, p. 318. John Tolan, in his recent history of Western perceptions of Muhammad, makes brief mention of Reland, but largely reduces him to the status of a source for the work of Sale. See Tolan, Faces of Mohammed, p. 163. See, however, the various publications of Alistair Hamilton mentioned below; in addition, see Pfannmüller, Handbuch, pp. 63-64, who credits Reland with 'the first scientific account of the Mohammedan religion'; Waardenburg, 'Mustashrikūn', p. 741b, who calls Reland's De religione Mohammedica 'the first enlightened study of Islam as a religion'; and Schimmel, 'Abendländische Islamstudien', pp. 27-28, who puts Reland on par with Sale. In his brilliant study of the Republic of Arabic Letters, Alexander Bevilacqua gives Reland ample space but also accuses him of a certain 
contribute to the change in European attitudes toward Islam, and the prophet Muhammad in particular? In order to answer this question, first we survey the major strands of thinking about Muhammad among 17th- and 18th-century Europen intellectuals, as exemplified by Hugo Grotius (1583-1645), Humphrey Prideaux (1648-1724), Henri de Boulainvilliers (1658-1722), and Voltaire (16941778). These writers worked in proximity to, but were not themselves members of the Republic of Arabic Letters. However, they deserve our attention because we can legitimately assume that their works reflect broadly shared sentiments in Europe at the time. Moving on, in a second step, from the widely circulating ideas of these public intellectuals, we examine the learned literature on Muhammad produced by the representatives of the fledgling scholarly guild of professional Arabists and Islamicists around 1700. The article 'Mohammed' in Barthélemy d'Herbelot's (1625-1695) groundbreaking Bibliothèque orientale (1697) provides a particularly fertile backdrop against which to evaluate Reland's assessment of the prophet of Islam. On this basis, we can proceed to ask to what extent Lessing's judgement is valid, that is, whether Reland's work represents a truly new and different view of Muhammad in the Western encounter with Islam. Finally, we ask in what ways Reland's Muhammad survives in the works of some later 18th- and 19th-century authors.

\section{Muhammad in 17th- and Early 18th-Century European Thought}

For large parts of the 17th century, the Ottomans' expansion into eastern and southern Europe inspired Christian writers working not just in the southern Catholic but also in the central and northern European lands to formulate vitriolic attacks on Islam and its prophet Muhammad. In his magnum opus, De iure belli ac pacis (The Law of War and Peace), first published in 1625, Hugo Grotius shows himself to be suprisingly uninterested in the Ottoman question, presumably out of an anti-Habsburg sentiment. Grotius even voices a measure of appreciation for the Muslim law of war, urging his Christian audience to follow the example of the Muslims, by rejecting the permissibility of enslaving prisoners of war. ${ }^{5}$ However, in his Dutch parenetic poem, Bewys van den waren godsdienst (Proof of the True Religion), published in 1622, Grotius is thoroughly

partisanship, that is, an 'assimilative bias - a tendency to overstate the resemblance of Islamic beliefs to Christian ones'. See Bevilacqua, Republic of Arabic Letters, p. 97. By contrast, Sale 'arbitrated between similarity and difference [between Islam and Christianity] more fair-mindedly than any of his ... predecessors'. See ibid., pp. 88-89.

5 See Kelsay, 'Islam and Christianity', p. 212. 
critical of Muhammad, and of Islam. Islam, according to Grotius, is a religion 'founded on violence.' ${ }^{6}$ While even the Qurān, as Grotius notes with a degree of satisfaction, speaks of Jesus as the 'spirit' and the 'word' of God, there can be no doubt that Muhammad was begotten naturally, the son of human parents. ${ }^{7}$ Not only that: he was a 'robber and an adulterer'. ${ }^{8}$ Likewise, those who followed him were 'people used to making a living off robbery'. ${ }^{9}$ In sum, Christianity is moderate, Islam extreme: it is grossly licentious in certain ways (Grotius points to the Prophet's polygamy) and senselessly ascetic in other respects (Grotius refers to Islam's prohibition of wine and pork). ${ }^{10}$

As if to cap his roundabout condemnation of Islam as being contrary to reason and to human nature, and to demonstrate the gullibility of its adherents, Grotius makes reference to several alleged miracles of Muhammad. Jesus, he reminds his audience, performed true miracles: he cured the sick and revived the dead. Muhammad, however, did not produce miracles; he only brought the sword. Grotius continues:
But some, it seems, to support his creed, attributed miracles to him, of which a part, may have happened by mere human art, such as a dove flying to a man's ear. ${ }^{11}$

The 'dove flying to a man's ear' alludes to the legend, already told in the 13thcentury Golden Legend of Jacobus da Varagine (1228-1298) and repeated by Boccaccio in the 14th century, William Shakespeare in the 16th century and Walter Raleigh in the early 17th century, of Muhammad tricking the Meccans into following him by means of a trained dove. According to this story, Muhammad put seeds in his ear and let a dove pick at them while preaching to the Meccans, so that they would believe that he was inspired by the Holy Ghost. ${ }^{12}$ Three of the alleged 'sins' that were stereotypically foregrounded in

6 Grotius, Bewys van den waren godsdienst, p. 126: 'gegrondet op geweld'.

7 Ibid., p. 128: 'een bloot mensch'.

8 Ibid., p. 128: 'Mahumet heeft rooff en overspel bedreven'.

$9 \quad$ Ibid., p. 129: 'Syn luy geweest gewent te leven op den rooff'.

$10 \quad$ Ibid., pp. 130-131.

11 Ibid., p. 129 : 'Doch eenigen, soo 't schynt, om syne leer te styven, / hem tegen sijnen dank ook wonderen toeschryven: / Waar van een deel door kunst soo wel geschieden kan, / Als dat een duyff aen 't oor komt vliegen van een man'.

See Bevilacqua, Republic of Arabic Letters, pp. 89-92. 
medieval European representations of Muhammad ${ }^{13}$ - his imposture, sensualism and violence - thus survive intact in the thought of Grotius.

The Ottoman threat to Europe waned after the Ottomans' failure to capture Vienna in 1683. In the ensuing 'period of relative calm', as Ahmad Gunny has observed, there came about 'the right atmosphere for a balanced reevaluation of the Prophet by the West. ${ }^{\prime 4}$ However, not everybody rose above politics. Following Grotius, many, in fact, preferred to continue in the old polemical vein. One of the most elaborate denunciations of Muhammad, written around the turn of the century, is The True Nature of Imposture (1697), by Humphrey Prideaux, Dean of Norwich. In this work, Prideaux casts aside the old fables, such as the story of the dove, claiming to offer an objective account of Muhammad. ${ }^{15}$ Yet in the conclusion to his biographical sketch of Muhammad, Prideaux is relentlessly hostile. He castigates Muhammad's 'ambition' and 'lust', his greed for power and for women, which, as Prideaux maintains, Muhammad sought to satisfy by 'inventing' Islam and imposing it on his 'deluded' followers. ${ }^{16}$ Prideaux writes as an orthodox Anglican keen to defend traditional belief against the Christian Deists, who rejected organized religion and were quick to criticize traditional Christianity as an imposture, instead promoting the rational observation of nature as the only valid way to God. ${ }^{17}$ The 'true' impostor, Prideaux aims to show, is Muhammad, not the Church.

Writing on the other side of the English Channel, a defense of the Church, whether Anglican or Catholic, was not at all in the interest of Voltaire, who was, after all, a famous Deist. However, as for Muhammad's imposture and lustfulness, he agreed with Prideaux. Voltaire, who had read Prideaux's work during his exile in England, ${ }^{18}$ popularized the notion of Muhammad as a power-hungry, cynical and hypersensual vilain in his anti-religious tragedy, the theatrical blockbuster Le fanatisme, ou Mahomet le prophète (Amsterdam, 1736). Even if in later works, Voltaire showed himself to be more judicious in his assessment of Muhammad and of Islam (he was full of praise for Sale's Qur'ān translation and 'Preliminary discourse', which he read shortly after writing his tragedy), Le fanatisme thrived on, and entrenched, the virulently antireligious rhetoric of the radical French enlightenment. Already a generation earlier, the French-reading atheist public had been fed stories of Muhammad's

\footnotetext{
13 Daniel, Islam and the West, pp. 92-93, 118-121, 158 and passim; Tolan, Saracens, pp. $135^{-169}$ and passim; Lange, Mohammed, pp. 111-112.

14 Gunny, The Prophet Muhammad, p. 21.

15 Bevilacqua, Republic of Arabic Letters, p. 90.

16 Prideaux, True Nature of Imposture, pp. 132-133.

17 Dimmock, Mythologies, pp. 180-181.

18 Reeves, Muhammad in Europe, p. 159.
} 
unscrupulous character in the shape of the notorious atheist manifesto, the Traité des trois imposteurs (compiled, in its French form, during the last quarter of the 17th century). $\cdot{ }^{19}$ For example, the Traité tells the tale of an accomplice of Muhammad, who speaks to the credulous Meccans from a pit, pretending to be the voice of God supporting Muhammad's claim to prophecy. ${ }^{20}$

Against the likes of Grotius, Prideaux and the Voltaire of Le fanatisme, there were also authors of the 17th and 18th centuries, such as Thomas Erpenius (1584-1624), professor of Oriental languages at Leiden, who were less biased. Erpenius' cautious openness toward Islam may have been motivated, among other things, by his acquaintance with the Morisco Aḥmad b. Qāsim al-Hajarī, a Moroccan emissary to France and the Netherlands (1611-13), by whom he was favourably impressed. Al-Hajarī visited Erpenius in Leiden in 1613 and discussed the promised 'paraclete of the gospel' with him (see John 14:16: 'And I will ask the Father, and He will give you another advocate [Gr. paráklētos]'), which he told him was a reference to the coming of the prophet Muhammad. As al-Hajarī claimed, Erpenius 'felt attracted to our religion'.21 'We have frequent discussions about religion', Erpenius wrote in a letter, 'but believe me their discussions are not so easy to refute as many people imagine. They abhor especially the godhead of Christ [and] about many other things they do not think as stupidly as some of us try to prove by means of the Qur'an.22

Protestant intellectuals were appreciative of Islam's iconoclasm, not least because of the deep grudge they held against Catholicism and all forms of 'popery'. As al-Hajarī put it, the Protestants, led on by Luther and Calvin, rejected the Pope and the idol-worship of the Catholics, believed in the falsification (tahrīf), by later generations, of the original gospel taught by Jesus, and appreciated the Muslims' role in history as 'the sword of God in the world against the idol-worshippers.'. ${ }^{23}$

The 1657 Dutch Qurān translation of Jan Hendriksz Glazemaker (ca. 16201682), which was based on the 1647 French translation of André Du Ryer, (ca. 1580-166o or 1672), also foreshadows Reland's later agenda to listen

19 The dating of the Traité, which is based on earlier polemical works (some of them medieval), is the subject of scholarly controversy. Here I follow the assessment of Schröder, 'Einleitung', p. xix.

$20 \quad$ Traité, pp. 106-9 (§ 22).

21 Translated by Wiegers, A Learned Muslim Acquaintance, p. 58. Much against al-Hajarī, Johann Fück noted that Erpenius held Muhammad to be an impostor, the Qurān a travesty of the Bible, and that he had 'no sympathies for the religion of Islam'. See Fück, Die arabischen Studien, pp. 69, 71.

22 Translated by Wiegers, A Learned Muslim Acquaintance, p. 5 ०.

23 Ḥajarī, K. Nāṣir al-dīn, p. 33. 
attentively to Muslim authors and provide an impartial account of Muhammad. Glazemaker appended two different versions of Muhammad's lifestory to his translation, one based on an eastern source, ${ }^{24}$ another on various hostile biographies written by European authors, 'so that the attentive reader will himself notice the differences and contradictions, and judge them, if he wills, as he sees fit'. ${ }^{25}$ In the second half of the $17^{\text {th }}$ century, there are even examples of Protestant authors lionizing Muhammad. The English Unitarianist Henry Stubbe (1632-1676), in his Originall \& Progress of Mahometanism (ca. 1671), is full of praise for Muhammad, calling him an 'extraordinary person' with 'ready wit', 'penetrating judgement' and 'undaunted courage', 'a person cut out for great achievements and equally qualified for actions of war, or the arts of peace and civil government. ${ }^{26}$ As Matthew Dimmock has remarked, Stubbe's concern was to portray Muhammad 'as the true inheritor of an original Christianity, unpolluted by priestcraft or popery'.27 'Sympathetic identification with Islam' allowed English radical Protestantism to achieve 'historical, philosophical, and ideological coherence. ${ }^{28}$ Also Henri de Boulainvilliers, in his much-read Vie de Mahomed (1730), used Muhammad towards anti-clerical ends, declaring him to be a wise lawgiver and a true prophet, sent to wash out the moribund decadence of late-antique Oriental Christianity. ${ }^{29}$ Not unlike Voltaire's Le fanatisme, but based on a diametrically opposed view of Muhammad, de Boulainvilliers' book is a covert attack on the Church.

Voltaire and de Boulainvilliers are late representatives of two dominant trends in the early modern European view of Islam and its prophet. Voltaire sketched a carricature of Muhammad as the embodiment of the moral corruption and cynical authoritarianism of religious leadership in general. De Boulainvilliers, who did not exactly write in an even-handed manner either, pitched Muhammad as a just ruler and wise lawgiver, a great leader who became the postmortem victim of an intrigant clergy assuming the reins of power after his death. In sum, both Voltaire and de Boulainvilliers unmistakably used Muhammad towards their own ulterior ends.

24 This was the chronicle of Georgius al-Makīn ('Elmacinus') Ibn al-'Amīd from Cairo (d. 1273), in Erpenius' Latin translation. On al-Makīn, see below.

25 Glazemaker, Mahomets Alkoran, p. iv.: '... op dat d'opmerkende lezer zelf 't verschil, en de strijdigheid daar in zou bemerken, en, zo 't hem lust, naar zijn eige believen daar af oordelen'. I owe this reference to Lucas van der Deijl.

26 Stubbe, Account, pp. 141-142. For a long time, Stubbe's text circulated in manuscript form, only to be published in the 20 th century.

27 Dimmock, Mythologies, p. 186.

28 Garcia, 'A Hungarian Revolution', p. 1.

29 See Gunny, The Prophet Muhammad, pp. 113-123. 
None of the authors discussed so far, to the exception of Erpenius, were scholars trained in the languages or the history of the Islamic world. As we would say today, they wrote from the perspective of 'world history', and always with the history and current situation of Europe as their main concern. What, then, of the intervention of specialised scholars of Arabic and Islamic history in the early modern debate about Muhammad? Were these scholars able to transcend the Eurocentric perspective of their more famous contemporaries among the philosophers and Christian theologians, and provide an account of Muhammad that was more historically accurate and true to the Islamic tradition?

In the second half of the 17th century, a generation after Erpenius, the Italian Ludovico Maracci (1612-1700), the Englishman Edward Pococke (1604-1691) and the Frenchman Barthélemy d'Herbelot (1625-1695) form a stellar triad among the scholars of the Republic of Arabic Letters. Of these three men, d'Herbelot was the most closely connected to Reland: Antoine Galland (1646-1715), the French Orientalist who brought d'Herbelot's stupendous Bibliothèque orientale to publication two years after the latter's death, counted among Reland's acquaintances. The fascinating gestation of d'Herbelot's Biblothèque has recently been studied, with admirable perspicacity, by Alexander Bevilacqua. ${ }^{30}$ Here, we limit ourselves to taking a closer look at the Bibliothèque's entry on Muhammad. ${ }^{31}$

This entry counts ten columns-a fairly lengthy treatment, but still noticeably shorter than, for example, the articles d'Herbelot dedicates to Genghis Khan and Timur. D'Herbelot invokes an impressive range of Arabic and Persian sources. It is striking that all works of history on which d'Herbelot relies to tell Muhammad's biography are the works of Christian authors: the Nazm aljawhar (The String of Jewels) of Eutychius Ibn Bațrik of Alexandria (d. 940), known in the West under the title Eutychii annales, in the partial edition and translation of Edward Pococke (1658-59); the world chronicle of Abū al-Faraj ('Aboulfarage') Gregorius Bar Hebraeus from Antioch (d. 685/1286), edited by Pococke under the title Specimen Historiae Arabae (1650 [1663]); and the world chronicle of Georgius al-Makīn ('Elmacinus') Ibn al-'Amīd from Cairo (d. 1273), partially edited by Erpenius and published by his student Jacobus Golius (1596-1667) under the title Historia saracenica (1625). D'Herbelot's reliance on Christian historians is not happenstance: he knew the works of

$30 \quad$ Bevilacqua, Republic of Arabic Letters, pp. 108-135.

31 D'Herbelot, Bibliothèque, pp. 598a-6o3b. See also Gunny, The Prophet Muhammad, pp. $3^{2-} 35$. 
Muslim historians, but—assuming he had access to them-chose not to use them. The most elaborate biographies of Muhammad, he notes toward the end of the entry, were written by 'Nouairi in the fourth part of his history written in Arabic and by Mirkhond in his Persian history'. These works are the fifth chapter, dealing with the biography of Muhammad and the early caliphs, of the fourth book, on history, of al-Nuwayrì's (d. 733/1333) massive literary anthology, the Nihāyat al-arab (The Ultimate Ambition), and the Rawdat al-șafä (Garden of Purity) of the Persian chronicler Mīrkhānd (d. 903/1498). D'Herbelot mentions these two works immediately after discussing a number of pious and mystical works about Muhammad. This suggests that he did not think of al-Nuwayri and Mīrkhānd as trustworthy sources. At least he did not consider them more reliable than Eutychius, Bar Hebraeus and al-Makīn. ${ }^{32}$

Next to providing the skeleton of biographical events of Muhammad's life, d'Herbelot draws particular attention to the Muslim mystical literature about Muhammad, as well as to the Muslim belief in Muhammad's existence as a 'luminous substance' prior to the creation of the world, a notion that strikes him as an 'extravagance.. ${ }^{33}$ For these aspects, d'Herbelot draws from the 'Bahar alhacaiq', that is, the Bahr al-haqāiq (The Sea of [Mystical] Truths) of Najm al-Dīn al-Rāzī (d. 654/1256), a Qửān commentary in the Kubrāwiyya Sufi tradition; the 'Methneui', that is, the Mathnavì of Rūmì (d. 672/1273); and the 'Nacdalnossous', that is, the Naqd al-nușuṣs (Critique of Texts) of Jāmī (d. 898/1492), a commentary on the Naqsh al-fușuṣ (Imprint of the Bezels [of Wisdom]) of Ibn al-'Arabì (d. 638/1240). Later on, he further refers to al-Futuhāt al-makkiyya (The Meccan Openings) of Ibn al-'Arabī and the Nafahăt al-uns (Breezes of Intimacy), again of Jāmī, both wellknown works. But this is not all: d'Herbelot also demonstrates familiarity with the famous mysticial poem dedicated to Muhammad, the Qașídat al-burda (Poem of the Mantle) of al-Būṣìnī (d. ca. 695/1295), works of the genre of 'The names of the Prophet' (asma $\bar{a}^{\text {' }}$ $a l-n a b \bar{\imath})$, as well as a string of other texts. Whether he actually had read all these works, of course, one may doubt. As others have noted, d'Herbelot relied extensively on the Ottoman polymath Kātip Çelebi's (d. 1068/1657) monumental annotated bibliography, the Kashf al-zunūn (Unveiling of Thoughts). All

32 None of these three authors commands the attention of historians of early Islam today, their works having long been supplanted by the likes of the Sira of Ibn Hishām (d. ca. 215/830) or the Ta'rīkh (History) of al-Tabarī (d. 310/923), both edited in the second half of the 19th century, by a German and a Dutch scholar, respectively. However, as Alistair Hamilton rightly remarks, both al-Makīn and Bar Hebraeus were not interested in anti-Islamic polemics: both wrote for a Christian as well as a Muslim audience. See Hamilton, 'Study of Islam', pp. 175, 177.

D'Herbelot, Bibliothèque, p. 6оза. 
in all, however, it cannot be denied that d'Herbelot's entry on Muhammad is astonishingly learned.

This erudition, however, does not prevent d'Herbelot from indulging in derogatory language and from invecting against several aspects of Muhammad's life and afterlife, in particular as regards his alleged imposture, his warmongering, and the exaggerated, superstitious devotion of his followers. ${ }^{34}$ Muhammad, he declares, is 'the famous impostor', ${ }^{35}$ an 'ignorant' 36 person who 'played comedy until the end of his life.' ${ }^{37} \mathrm{He}$ also notes that Muhammad's pagan enemies called him abtar, 'sans queue', because 'he did not leave any male progeny, despite having 21 wives'. ${ }^{38}$ To respond to this mockery, Muhammad would have declaimed the 108th chapter of the Qur'an, sūrat al-Kawthar. Whether or not there is a sexual innuendo here on the part of d'Herbelot (the translation of abtar as 'sans queue' was apt to amuse some of his readers), his mentioning of sürat al-Kawthar again evinces his familiarity with the Arabic sources. The Qurân exegetes did indeed relate that on the death of Muhammad's infant son, al-Qāsim, some of Muhammad's contemporaries observed that he had become curtailed (abtar) of his son. In response, to make up for the loss suffered by Muhammad, God revealed 'We have given you abundance, so pray unto your Lord and sacrifice, for those who hate you, they are the ones cut off (abtar)' (Qur'ān 108:1-3). ${ }^{39}$

As for Muhammad's warfare, d'Herbelot maintains that Muhammad was hellbound on bloodshed. Having fled to Medina, Muhammad would have insisted, against his followers' unanimous advice, that a Meccan caravan be attacked, an event that sparked the first battle, at Badr, in the war against pagan Mecca. ${ }^{40}$ Finally, in several places of his entry, d'Herbelot draws attention to the 'outré' superstitious beliefs of Muslims in Muhammad's theurgical powers, including his ability to intercede on behalf of the believers on the Day of Judgement, and in the magical properties of Muhammad's name. He refers, specifically, to a work by one Hianbalī author, 'Uthmān al-Futūhị, titled Bushrā al-karìm al-amjad bi-'adam ta'dhïb man yusammā Aḥmad wa-Muhammad (The

\footnotetext{
34 As noted by Ahmad Gunny, d'Herbelot's articles on 'Din' and 'Eslam' are more 'balanced'. See Gunny, The Prophet Muhammad, p. 31.

35 D'Herbelot, Bibliothèque, pp. 598b, 599a.

36 Ibid., p. 599a.

37 Ibid., p. 6o2b.

38 Ibid., p. 6o3a.

39 Suyūțī, Durr, vol. 8, p. $65^{2}$.

40 D'Herbelot, Bibliothèque, 6ooa.
} 
Good Tidings Given by the Exalted Generous [God] about the Fact that Those Who Are Called Ahmad and Muhammad Will Not Be Punished [in the Hereafter]).41

The tendency to elevate Muhammad to the status of a supernatural, salvific figure is not as uncharacteristic of Muslim devotional attitudes as some have claimed ${ }^{42}$ The notion of Muhammad's pre-existing light (the nür Muhammad), for example, enjoyed great popularity throughout Islamic history ${ }^{43}$ However, it is difficult to avoid the impression that d'Herbelot takes a certain delight in foregrounding the more extreme mystical and cosmological speculations attaching to Muhammad. Even though, unlike earlier European polemicists, he does not seem interested in Muhammad's alleged sexual licentiousness, overall he takes a one-sidedly harsh view of him. The imbalance of d'Herbelot's portrait of Muhammad appears to jar with his overall intention to 'provide an accurate description of Islam, not to attack it'.44 Did d'Herbelot feel obliged, in the case of Muhammad, to pay lip service to the Catholic environment in which he operated? The Bibliothèque orientale, after all, is dedicated to the 'Rex Christianissimus', the French king Louis XIV, who was d'Herbelot's patron, paying him a handsome annual pension. ${ }^{45}$ Be that as it may, European scholars writing around the year 1700, despite the progress booked by erudite Arabists and Islamicists like Maracci, Pococke and d'Herbelot, were still miles away from an impartial assessment of Muhammad.

Muhammad in Reland's De religione Mohammedica (1705) and His De jure militari Mohammedanorum (1708)

As we saw above, Erpenius in Leiden had paved the way for the study of the Islamic world based on first-hand knowledge of Arabic sources and undertaken in conversation with Muslim interlocutors. At Utrecht, Erpenius' onetime student Voetius (1589-1676) took a different approach. Voetius, one of the founding fathers of the University of Utrecht, was a systematic theologian of the Reformed Church, a scholar of Oriental languages, and an outspoken critic of Copernicus, Descartes and Spinoza. In his Disputatio de Mohammedanismo (Disputation regarding Mohammedanism, 1648), he relies, as his most important source, on the Confusio sectae Mahometanae (Confusion of the Sect of

41 Ibid., p. 6oza. A manuscript of this work is mentioned by Kātip Çelebi. See Kātip Çelebi, Kashf, vol. 2., p. 54 .

42 Gunny, The Prophet Mohammed, pp. 32-33.

43 See Rubin, 'Pre-Existence and Light'.

44 Bevilacqua, Republic of Arabic Letters, p. 129.

45 Fück, Die arabischen Studien, p. 99. 
Muhammad) of the Spanish convert Juan Andrés (fl. ca. 1487-1515), a polemic, inter alia, against the Muslim failure to understand the Christian trinity and against the sensuality of the Muslim afterlife. ${ }^{46}$ Voetius points out that Muhammad 'contradicted himself' in several places in the Qur'ann, which, the reader is made to gather, makes it easy to come up with arguments against him. ${ }^{47}$ Further, Voetius maintains that Muhammad, a 'possessed maniac' (Lt. 'maniaco-energumenicum') and 'impostor', suffered from epilepsy. ${ }^{48}$

The polemical Grotius and Voetius, the vituperative Prideaux, the learned but dismissive Maracci, Pococke and d'Herbelot, but also the cautiously curious Erpenius: these were the scholars of whose ideas we may assume Reland was aware, and with whom and against whom he developed his own view of Muhammad. This happened only gradually. In one of his early works, written as a twenty-year-old student in Utrecht, the Exercitatio philologico-theologica de symbolo Mohammedico (Non est Deus nisi Unus) adversus quod S.S. Trinitas defenditur (A Philological-Theological Investigation of the Muslim Creed [There is no God but God], against Which the Holy Trinity is Defended, 1696), he squarely dismissed Islam as a dangerous heresy, and Muhammad as a 'pseudo-prophet' and 'impostor'49 In De religione Mohammedica, however, the tone is markedly different, even if it is never as celebratory as, for example, in the works of Stubbe or de Boulainvilliers. Granted, De religione Mohammedica is not primarily a book about Muhammad. The distinction of having written the first balanced biography of Muhammad based exclusively on Muslim sources belongs to Jean Gagnier (ca. 1670-1740), professor at Oxford, who published his De vita et rebus gestis Mohammedis in $1723 .{ }^{50}$ Reland's De religione Mohammedica,

46 Vrolijk and Van Leeuwen, Arabic Studies, p. 64; Van Amersfoort and Van Asselt, Liever Turks dan Paaps?, p. 22.

47 Voetius, Disputatio, p. 662 (tr. pp. 63-64).

48 Ibid., p. 671 (tr. pp. $75^{-76}$ ).

49 See Hamilton, 'Reland and Islam', p. 245. In a congratulatory poem written in Arabic on the occasion of the Exercitatio philologico-theologica de consensu Mohammedanismi et Judaismi, Reland's friend and tutor, Heinrich Sike (1669-1712), slandered Muhammad as a pseudo-prophet who falsely claimed divine revelation, and who is accordingly punished in hell by being fed the fruits of the infernal tree of Zaqqūm (Qur'ān 56:52 and passim) and made to drink the 'boiling water' with which sinners are threatened in the Qurān (Qur'ān 55:44 and passim). The poem is appended, on the last page (no page number), to Reland, Exercitatio philologico-theologica. In his Exercitatio, Reland is rather stereotypically derogatory of Muhammad, even though in his De libertate philosophandi, written two years earlier, he had fully embraced, at least in principle, the imperative for intellectual freedom and rejection of the authority of earlier scholars. See Henk van Rinsum's chapter in this volume. For a translation of Sike's poem, see the appendix of the present volume.

$5^{\circ}$ Gagnier followed up on his Vita with an enlarged and more widely read French version, La vie de Mahomet, published in Amsterdam in 1732. See Gagnier, Vie de Mahomet. 
by contrast, paints a much wider canvas. But it is worthwhile to focus for a moment on those passages in De religione Mohammedica that deal explicitly with the prophet of Islam.

First, let us highlight that Reland makes short work of some of the more fanciful and factually incorrect claims about Muhammad circulating in 17thand early 18th-century European literature, such as the legend of the dove. Reland calls it an absurd idea that the Arab authors should have failed to mention this legend, if indeed there was any truth to it, considering that 'they bring to the attention other miracles about Muhammad that seem far less realistic, for example, that the moon descended towards him, that the trees greeted him, etc.51 Grotius, as will be remembered, had given credence to the story, and it may well be that Reland here reacts to what he perceived as the shortcoming of his illustrious Dutch predecessor. In fact, it is tempting to think that Reland's twin publications, De religione Mohammedica and De jure militari Mohammedanorum (Treatise of the Mahometans' Law of Warfare, first published 1708, also appended, as 'Verhandelinge van het Krygs-recht der Mahometaanen', to the 1718 Dutch version of De religione Mohammedica), were conceived as a response to Grotius' Bewys van den waren godsdienst and De iure bellic ac pacis, as if aiming to supersede and replace the work of a scholar with no first-hand knowledge of the Islamic tradition with the careful scrutiny of a scholar of Oriental languages and Islam.

Reland also takes aim at the pernicious Western idea that Muhammad's grave is in Mecca, ${ }^{52}$ where his coffin was supposedly suspended, by means of a magical trick, between the floor and the roof of his mausoleum. This legend was disseminated all over medieval Europe thanks to Petrus Alphonsi's (d. 1140) Dialogi contra Iudaeos (Dialogues against the Jews). As has been suggested, the legend served to illustrate that Islam was 'an inversion of Christian worship.'53

Pfannmüller, Handbuch, p. 171, sees in Gagnier's work the first scholarly study of Muhammad by a Western scholar, but Ehlert, 'Muhammad', p. 382a, states that Gagnier's work is no more than 'a polemic against Boulainvilliers and a denigration of Islam'. See the useful summary of this controversy by Bennett, 'Jean Gagnier'.

51 Reland, Verhandeling, p. 188. Here and in the following, I quote Reland's De religione Mohammedica and De jure militari Mohammedanorum from their 1718 Dutch translation. For a noteworthy difference between the 1705 and 1717/1718 editions of De religione Mohammedica, see below, at n61.

$5^{2} \quad$ A view also held by Voetius, see Voetius, Disputatio, p. 666 (tr. p. 68).

53 Moore, The Architecture of the Christian Holy Land, p. 159 (I owe this reference to Jo Spaans). See also Pellat, 'Note sur la légende'. It is interesting to note that early Muslim geographers told similar stories about the Greek pagans (a magnetic statue constructed by Apollonius of Tyana), as well as the Hindus of Gujarat. See Dietrich, 'Maghnāțīs', p. 1168a. Similarly, the Mamluk chronicler Ibn Kathīr (d. 774/1373) related that Genghis 
Reland notes that Muhammad's grave is in Medina, not in Mecca, and that the belief that his coffin is suspended in the air is incorrect. In the manner of a modern historian of religion, he speculates about the origins of the story: 'Similarly, it is recounted about a certain statue in the Temple of Serapis that it was suspended between the floor and the roof by means of a magnet placed in the roof of the temple. ${ }^{54}$

It may not have been particularly difficult for Reland to debunk the hackneyed factual misconceptions about Muhammad, and he was hardly the first to do so. Erpenius had already exploded the myth of the suspended coffin, ${ }^{55}$ and Pococke had upbraided Grotius for relating the legend of the dove. ${ }^{56}$ It is on another level that Reland's innovative views of Muhammad come to the fore, namely when he engages with two accusations made by d'Herbelot, that is, first, that Muhammad was a warmongerer and second, that the veneration granted to Muhammad in Islam is nothing but superstitious extravagance. Regarding the first of these accusations, in his Treatise of the Mahometans' Law of Warfare, Reland writes that

it deserves to be known that Mahomet, when he first claimed that he was sent as a prophet of God [...], did not encourage his people to go to war, but counseled against it, admonishing them that one should patiently bear one's enemies' injustices. Then, when he had increased in wealth and power, he stated that it was allowed for him and his people to defend themselves against the unbelievers. Finally, grown more and more in status, he openly declared that it was permissible to wage war against one's enemies at all times ... 57

This is a rather even-handed summary of Muhammad's attitude towards warfare, far more nuanced than what d'Herbelot had written. Reland is aware of the meek, early phase of Muhammad's career, in which he discouraged violence,

Khan was buried in an iron coffin, which was suspended between two mountains. See Ibn Kathīr, Bidāya, vol. 13, p. 118.

54 Reland, Verhandeling, p. 149. Cf. Tolan, Faces of Mohammed, p. 163: 'Reland uses comparisons with classical antiquity to valorize Islam both by associating it with the revered cultures of Greco-Roman antiquity and by removing it from a simple comparison with Christianity'.

55 See Hamilton, 'Study of Islam', p. 175.

$5^{6}$ Pococke, Specimen, pp. 186-187. Grotius, at the insistence of Pococke, agreed that the legend would be excised from Pococke's Arabic translation of Grotius's poem. See Bevilacqua, Republic of Arabic Letters, p. 89; Gunny, The Prophet Muhammad, p. 41; Fück, Die arabischen Studien, p. 87 .

Reland, 'Krygs-recht', p. 201. 
but which gave way, after the emigration from Mecca to Medina, first, to a legimitization of defensive warfare and second, to allowing warfare 'against enemies at all times'. In the end, Muhammad praised warfare against the unbelievers as a holy duty. However, Reland warns his readers, for this we should not condemn him too quickly - after all, several popes had behaved in the same way. ${ }^{58}$ In his attempt to normalize Islam, Reland then offers a paraphrase of a text dealing with the Islamic law of warfare, of which he possessed a manuscript and which he introduces by saying that 'recently, I managed to obtain a book, written in a sure hand, that contains in a convenient order the most important things that serve to illuminate this topic'.59 This text, the Shi'i legal compendium Jāmi'-i 'Abbāà (The 'Abbāsī Collection, in Persian) of Bahā’ al-Dīn al-Ámilī (d. 103o/1621), ${ }^{60}$ provides a standard summary of the most important

58 Ibid., p. 203.

59 Ibid., pp. 200, 257 (Dt. 'handschrift'). There is no work specifically dedicated to the law

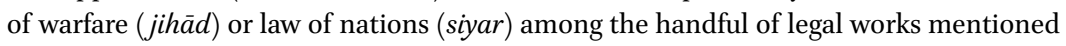
in the 'Index codicum Orientalium Manuscriptorum' appended to the 1705 edition of $D e$ religione Mohammedica (nos. 2, 3, 5, 18, 19, 22) or in the 1761 auction catalogue of Reland's manuscripts, the Catalogus librorum manuscriptorum (pp. 3 [no. 28], 1ofds [nos. 1 and 2], 12 [no. 25]). On several occasions in his text, Reland cites the opinions of Shāfíi jurists, contrasting them with 'the jurists of the Persians'. See Reland, 'Krygs-recht', pp. 249, 251-252. Reland possessed at least one Shāfíi legal manuscript, the Ghāyat al-ikhtișār (Ultimate Summary) of Abū Shujāc al-Iṣfahānī (fl. second half of 5th/11th c.), a well-known legal digest (matn). See 'Index', no. 18. We may assume that also the 'Systema Juris Sacri \& Civilis Muhammedanorum Arabice cum versione Malaica interlineari' ('System of sacred and civil law of the Muhammedans, Arabic with interlinear Malay') in the 1761 catalogue (Catalogus, p. 3 [no. 28]) is a Shāfi'ī work. One of Reland's other manuscripts, kept in the Leiden collection (Or. 1347,) is Abū Shujā's matn with interlinear Malay (see Arnoud Vrolijk's contribution to this volume). Abū Shujā's work, however, is rather too short to have served as the basis of Reland's relatively detailed discussion. The other Sunni legal works in Reland's possession cannot have served as his main source, either. The Risāla of Ibn Abī Zayd al-Qayrawānī (Mālikī, 4th/1oth century) ('Index', no. 5), like Abū Shujā's work, is too short. The two Hanafì works Kanz al-daqāंiq (The Treasure of Subtleties) of Aḥmad b. Muḥammad al-Nasafî (d. 710/1310) ('Index', no. 22) and Multaqā al-abḥur (The Meeting of the Seas) of Ibrāhīm b. Muḥammad b. Ibrāhīm al-Ḥalabī (d. 956/1549) (Catalogus, p. 12 [no. 25]) do not bear much similarity to Reland's treatment. See Nasafî, Kanz, pp. 369-391; Halabī, Multaqā, pp. 333-356. As is explained in the following footnote, Reland instead relied on a Shici text, written in Persian.

6o The Catalogus (p. 10 [no. 1] = 'Index', no. 3) describes this work as 'Giameng Abasi, h.e. Pandectae Abbasici sive Systema Juris Sacri \& Civilis Muhammedici Persici conscriptum Jussu Regis Schach Abas, divisum in 20. capita liber accuratissimus ... (Jāmici $i$ 'Abbāsī, or The Abbāsi Collection, or: System of sacred and civil law of the Persian Muhammedans, composed on the order of the king Shāh 'Abbās, divided in 20 chapters, a very accurate book ...)'. The sections on jihād in al-Āmilī's work (see 'Āmilī, Jāmi'-i 'Abbāsī, pp. 150-161 [§§ 143-149]) are titled as follows: § 143: Praise of jihād; § 144: Conditions for engaging in jihād; § 145: Jihād against hostile unbelievers; § 146: Modalities of jihād; § 147: Protections 
rules regulating warfare in Islamic law: that war is to be waged in defense of Islam; that war may only be declared by the head of state (the imām); that certain restrictions and regulations must be respected concerning the treatment of prisoners of war and of booty; and other such things.

Regarding the second of d'Herbelot's accusations, namely that Muhammad claimed quasi-divine status and as such is the object of superstitious devotion among his followers, Reland seeks to set the record straight, too. Muhammad, he avers, had a rather healthy awareness of human fallibility, including his own. Reland cites Qur'ān 10:98 ('If your Lord had willed, whoever is in the earth would have believed, all of them, all together'). This helps him to score a crucial point: Muhammad taught that 'all should be free to follow their own light, and to believe that to be true which thus seems to them'-a maxim with which Reland manifestly concurs. ${ }^{61}$ Muslims, Reland continues, know full well that Muhammad was a fallible human being. They even admit 'that Mahomet, with his own lips, spoke words which he did not believe to be true'.62 Here, Reland refers to the wellknown incident of the 'Satanic verses'. As the exegetes of the Qurān related, the devil misled Muhammad into reciting these verses, which praise a number of polytheistic deities. However, realizing his mistake, Muhammad later retracted and expunged them from the Qur'ān. ${ }^{63}$

guaranteed to defeated unbelievers; § 148: Rules about armistice; § 149: Rules about booty. As against what one finds in the works mentioned in the previous footnote, this coincides neatly with the sequence of topics in Reland's work. Also content-wise, there is ample overlap. For example, Reland reproduces the five-fold classification (ahkām) of acts of warfare that one finds in $§ 146$ of al-Āmilì's work (Reland, 'Krygs-recht', §§ 10-15). Reland's reliance on this text perfectly illustrates the 'usefulness' of studying Persian, a point he defended in his 1701 Utrecht inaugural address Pro lingua Persica et cognatis litteris Orientalibus (In Favour of the Persian Language and Cognate Oriental Idioms). He did not suffer from the Arabocentrism that has marred so much of Western scholarship on Islam in the 2oth and 21st centuries. Reland's manuscript of the Jämi' $i$ 'Abbāsī, now kept in Vatican library (MS Vatican, BAV, in 1763), was written in 1045/1636 in Hyderabad, and possibly reached Reland through Cornelis Mutter (1659-1701 or 1704), who had been stationed there before returning to the Dutch Republic in 1698. On Mutter's connection with Reland, see Bart Jaski's contribution to this volume. On Reland's contribution to the study of Persian, see De Bruijn, "The Persian Studies of Adriaan Reland".

61 Reland, Verhandeling, p. 115: '... zy het eenen iegelyken vry zyn licht te volgen, en te gelooven, dat dat geene waar is, 't geen hem alzo schynt' = idem, De religione Mohammedica (1717), p. 161: '... liberum sit unicuique lumen suum sequi, \& illud credere verum essere quod ipsi videtur'. It is noteworthy that this remarkable passage only occurs in the second, 1717 edition, not in the first, 1705 edition, of De religione Mohammedica, in the substantially enlarged fifth chapter of part two.

62 Ibid., p. 116.

63 See Ahmed, 'Satanic verses'. 
Another Western misconception Reland seeks to debunk is that Muslims believe that 'God prays for Muhammad'. ${ }^{64}$ Reland devotes chapter eight of his De religione Mohammedica to this question, in the second part of his work, which is entitled 'Book 2 over the Mahometan religion, treating some of the things that people accuse the Mahometans of without cause'. This misperception, Reland argues, is based on a mistranslation that ultimately goes back to Robert of Ketton's Latin rendering of the Qur'ān (see Qur'ān 33:56). ${ }^{65}$ This mistranslation concerns the formula șallä Allāhu 'alayhi, which Muslims are encouraged to recite after every mention of the name Muhammad. The verb șallā, Reland explains, does not only mean 'to pray', but also, 'to have a favourable opinion', and this is how the formula ought to be understood: 'May God have a favourable opinion of Muhammad'. Reland had ample resources at his disposal to reach such a conclusion. The 1761 auction catalogue of his manuscripts, the Catalogus librorum manuscriptorum, mentions no fewer than three works dealing with praise formulas for Muhammad, next to a manuscript of the story of his ascension, the mi'räj. ${ }^{66}$ And indeed, Reland's view finds support in the works of Muslim scholars, who generally understand șallā to mean 'to bless' ${ }^{67}$ In sum, Reland maintains that Muhammad is not unduly venerated in Islam, let alone deified. The point of the pilgrimage to Mecca is not to worship Muhammad in his allegedly flying coffin, but to participate in an ancient ritual, a religious ceremony anchored in the remote past of humankind, predating Islam..$^{68}$

64 Reland, Verhandeling, pp. 120-123: 'Of zy gelooven, dat God voor Mohamet bid'.

65 As Henk van Rinsum points out to me, already in his 1996 Exercitatio de symbolo Mohammedico is Reland skeptical with regard to Ketton's translation.

66 Catalogus, p. 6: 'no. 19: Collected blessings on Muhammad, by "Abdalla Muhammed Sokeiker Anhaswaliensi", in African script ...' This corresponds to De religione Mohammedica, 'Index codicum Orientalium Manuscriptorum', no. 14, where the author's name is given in Arabic as 'Anhazūlī', a garbled form of Abū 'Abdallāh Muhammad b. Sulaymān al-Jazūlī, d. 869/1465, the Moroccan author of a celebrated collection of devotional prayers on the Prophet, the Dalā'il al-khayrät. Further, Catalogus, p. 8: 'no. 41: Story of Muhammad's rapture ..., i.e. the hadīth al-mi'rāj (= 'Index codicum Orientalium Manuscriptorum', no. 12); ibid., p. 9: 'no. 6o: Several sermons and confessionary formulas in praise of Mahomet..., in Arabic'; ibid., p. 11: 'no. 14: A Persian book containing much in praise of Mohamet ...'

67 Meier, Segenssprechung, p. 1.

68 Reland, Verhandeling, p. 15 o. 
In what ways, if any, does Reland's treatment introduce new aspects into the European view of Muhammad? The gulf that separates him from the likes of Prideaux, Voltaire and de Boulainvilliers should by now be obvious on the basis of the above. But how does Reland's Muhammad compare to the Muhammad of his learned colleagues Pococke, Maracci and d'Herbelot? It is true, Reland continues to espouse the view shared by all these men that Islam should be studied first and foremost in order to refute it, and in this and other respects, 'his approach ... can only be regarded as highly traditional'.69 However, as I woud like to suggest here, the little shifts in perspective that Reland proposes add up to something more than just a cleverly 'partisan'70 extension of the works of earlier scholars of the Republic of Arabic Letters.

First of all, let us note, as others have done, ${ }^{71}$ the remarkable fact that Reland completely disavows the insulting epithets that his contemporaries so commonly use to denigrate Muhammad. Nor does he indulge in lavish praise of Muhammad as particularly wise, just, or courageous. Instead of dismissing him as an impostor or reducing his significance to that of a mere statesman, throughout De religione Mohammedica, Reland refers to Muhammad simply as 'prophet.' ${ }^{2}$ Already in his notes to the 1701 edition of the Dutch translation of Hayy Ibn Yaqzān (Rotterdam, Pieter Van der Veer), Reland had emphasised that the shahäda, the Muslim profession of faith, should not be rendered as 'I profess that God has not companion' (Dt. 'meede-genoot'), but ought also to include the formula 'and that Muhammad is his Messenger. ${ }^{73}$ In this context, it is also worth highlighting the straightforward manner in which Reland denounces the old fables about Muhammad, such as the belief that his coffin is suspended mid-air in the Kaba, or the story of the dove. As we saw above, others had preceded him in this, notably Erpenius and Pococke (though Maracci did, too), but d'Herbelot, in his Bibliothèque orientale, while steering clear of fables, makes no effort at all to reflect on earlier Western misconceptions. As for Maracci's and Pococke's attitudes toward Muhammad, the differences with Reland are palpable. As Snouck Hurgronje observed, while Maracci was unable to 'mention the name Muhammad without shivering', Reland's 'excellent little

\footnotetext{
69 Hamilton, 'Reland and Islam', p. 25o.

$70 \quad$ Bevilacqua, Rebublic of Arabic Letters, p. 97.

71 Hamilton, 'Reland and Islam', p. 245.

72 See Snouck Hurgronje, 'Une nouvelle biographie', p. 323.

73 Ibn Tufayl, De Natuurlyke Wysgeer, p. 2. On Reland's contribution to the publication of this work, see the chapter by Remke Kruk and Arnout Vrolijk in the present volume.
} 
book ... has a very different character'.74 Like Maracci, Pococke was thoroughly unsympathetic to Muhammad. He 'continued to look on Muhammad as the great impostor and Islam as the religion of the false prophet'. ${ }^{75}$ Things may have been different with George Sale, but he wrote a generation later, and under the influence of Reland's work. ${ }^{76}$

Secondly, there is something rather special about the way in which Reland goes about selecting his sources. 'All I can know about Muhammad's feelings', he declares in the preface to De religione Mohammedica, 'I must learn from his writings'.77 Similarly, he begins his Treatise on the Mahometans' Law of Warfare by noting that "we have a desire (Dt. "het lust ons") to relate the Mahometans' law of warfare on the basis of authentic (Dt. "echte") texts, and such as they themselves have determined it'.78 This 'desire' to go back to 'authentic' sources is present in the work of other early modern scholars of Islam, but again there are differences. Maracci is famous for relying on a broad range of Arabic-Muslim sources, but he often cites them only in order to ridicule them. ${ }^{79}$ Pococke and following him d'Herbelot rely on Arab Christian historians for their reconstruction of Muhammad's biography, which strikes one as problematic, even if it signals an important advance upon earlier uncritical reliance upon the Greek-writing Byzantine historians, which were more prone to distortion. ${ }^{80}$ It seems significant that in De religione Mohammedica, when telling the story of Muhammad's life, Reland refers the reader, not to the standard texts of Eutychius, Bar Hebraeus and al-Makin, but instead, to a short 'Turkish chronicle', the manuscript of which he had bought from Golius' Nachlass. ${ }^{81}$ Although Reland's apparent unwillingness to leave Utrecht restricted his ability to access manuscripts, we can still discern a distinct strategy to use specifically Muslim sources as much as possible. A splendid example of this is how Reland, in De religione Mohammedica, makes use of al-Ghazālì's (d. 505/1111) K. al-Arbaìn fì ușül al-dīn (The Book of Forty [Articles] on the Principles of Religion), a work that repeats, in a succinct form, many themes

\footnotetext{
74 Snouck Hurgronje, 'Une nouvelle biographie', p. 322.

75 Gunny, The Prophet Muhammad, p. 41.

76 Dimmock, Mythologies, p. 206.

77 Reland, Verhandeling, p. xlii.

78 Idem, 'Krygs-recht', p. 199.

79 Hamilton, 'Reland and Islam', p. 245.

$80 \quad$ Idem, 'Study of Islam', p. 175.

81 See Reland, Verhandeling, pp. 31-32, note (a).
} 
of al-Ghazâli's magnum opus, the Ihyā' 'ulüm al-dīn (The Revivification of the Religious Sciences), a pivotal work in the history of Islamic religious thought. ${ }^{82}$

Thirdly and finally, to what extent is it possible to credit Reland with the ambition to emancipate the European study of Islam and of Arabic from its roots in expansionist politics, Christian interreligious polemics and inner-Christian confessional conflict? The decisive push for the autonomy of Western Arabic Studies is commonly attributed to the German Johann Jakob Reiske (1716-74) and the Frenchman Silvestre de Sacy $\left(175^{8-1838)},{ }^{83}\right.$ and one cannot really disagree with this view. As opposed to de Sacy and Reiske, Reland openly declared that the study of Arabic was first and foremost a help to Hebrew philology. ${ }^{84}$ Besides, his versatility as a polymath scholar of languages, history, and religions, among other things, arguably undercut his ability to promote a single discipline, such as Arabic or Islamic Studies. ${ }^{85}$ Reland also held that Islam should be studied in order better to understand the enemy of Christianity. Occasionally, he was candid about this: 'We are forced', he wrote in his Treatise on the Mahometans' Law of Warfare, 'to fight the Indian and Persian Muslims'; this is why, according to Reland, it is 'useful' to study the Muslims' ideas about warfare. ${ }^{86}$ As noted, in many respects he was a man of traditionalist convictions.

However, Reland also points to the future. ${ }^{87}$ Crucially, he insisted on studying the beliefs and practices of Muslims on their own terms. Most of his predecessors, learned or not, plainly reduced knowledge of Arabic and Islam towards other ends. By contrast, from Reland's writings, Muhammad emerges as a man who 'spoke in his own language' and 'followed his own light', a prophet deserving of study, not in order to undermine the civilization that he spawned, but to come to an honest assessment of his character and achievement. Reland thus

82 Idem, De religione Mohammedica, 'Index codicum Orientalium Manuscriptorum', no. 1. It seems rather likely to me that this is the 'short' and 'well-respected' work that Reland used as the source text for the first part of De religione Mohammedica, the 'Compendium theologiae Mohammedicae'. See Reland, Verhandeling, xli-xlii. The K. al-Arba'in is divided in four parts: (1) matters of creed (al-'aqā'id); (2) ritual and 'outer behaviour' (al-a'māl al-z̧ăhira); (3) vices (al-akhlāq al-madhmūma); (4) virtues (al-akhlāq al-mahmmūda). See further Bouyges, Essay, pp. 50-51.

83 Fück, Die arabischen Studien, pp. 108-24 (Reiske), 140-157 (de Sacy); Vrolijk and Van Leeuwen, Arabic Studies, p. 82; Bevilacqua, Republic of Arabic Letters, pp. 141-43. Alistair Hamilton credits Reland with achieving a certain 'progress' but thinks of 18th-century scholars, including Reland and Reiske, as less innovative than 17 th-century scholars. See Hamilton, 'Study of Islam', p. 182.

84 Fück, Die arabischen Studien, 105; Hamilton, 'Outstanding Orientalist', p. 28.

85 See the pertinent remarks by Fück, Die arabischen Studien, p. 105.

86 Reland, 'Krygs-recht', p. 200.

87 Hamilton, 'Outstanding Orientalist', p. 28. 
may not have revolutionised the European view of Muhammad but he can be said to have acted as a switchman, almost imperceptibly changing the course of thought of later interpreters and of the educated public at large.

We should note, however, that in certain quarters, his success was quite limited. For example, from 1777 to 1779, there appeared in The Hague a revised and updated edition of the Bibliothèque orientale. The revisions were the work of Reiske and his Dutch mentor, the professor of Oriental languages at Leiden, Albert Schultens (1686-1750). Schultens, who was a mere ten years younger than Reland, met Reland in Utrecht in 1708 and throughout the 1710s, and must have been well acquainted with De religione Muhammadica. And yet, the entry on Muhammad in the revised edition of the Bibliothèque remained unchanged from the earlier version of d'Herbelot. In Diderot's and d'Alembert's Encyclopédie (1751-72), there is no separate entry on Muhammad, but he is mentioned in the two entries written by Louis de Jaucourt, 'Alcoran' and 'Mahométisme', to an overall uneven effect. While in the entry 'Alcoran', we are back in the arena of Byzantine polemics-Muhammad is the 'false prophet' who composed the Quraan with the help of 'Batyras, a Jacobite heretic, Sergius, a Nestorian monk, and some Jews'-, the entry 'Mahométisme' seems inspired by de Boulainvilliers' enthusiasm: Muhammad had the 'audicity of Alexander the Great, but also the generosity and sobriety that Alexander lacked', while parts of the Qur'ān, a text deemed generally 'incoherent' and full of 'contradictions, absurdities and anachronisms', are 'sublime., ${ }^{88}$ Reland's name does not appear in the Encyclopédie, to the single exception of a brief mention in the entry on the Greek city of Thebes.

Reland was more successful at home, in the Netherlands, and in the northern Protestant countries. When Jean Gagnier, a French refugee who taught Oriental languages at Oxford, published his biography of Muhammad (1732), in a spirit congenial to Reland he made sure to let only 'the best Arab authors' speak to the topic, having previously, in 1723, edited and translated (into Latin) the life (sìra) of Muhammad of the Syrian Muslim historian, Abū al-Fidä' (d. 732/1331). ${ }^{89}$ Reland also paved the way for Bernard Picart's and Jean-Frédéric Bernard's Cérémonies et coutumes religieuses de tous les peuples du monde (Amsterdam 1723-43), dubbed in recent scholarship, because of its massive commercial success and its decentering of European views of other

88 Encyclopédie, s.v. Alcoran, vol. 1 (1751), pp. 250a-251b; s.v. Mahométisme, vol. 9 (1765), pp. 864a-68b. See Pfannmüller, Handbuch, 172: '[Regarding Muhammad,] the encyclopedists and their friends repeat, with typical hyperbole, the formulas of Voltaire'.

89 Abū al-Fidā', De vita et rebus gestis Mohammedis. 
peoples, 'the book that changed Europe..$^{90}$ The fifth volume, published in 1737, is devoted to Islam. Picart, the engraver, used the engraving of the Ka ba featuring in the second edition of De religione Mohammedica, the same image that was also included in the front matter of George Sale's Koran of $1734 \cdot{ }^{91}$ Bernard, the author, compiled his text from the writings of de Boulainvilliers, d'Herbelot and Sale, but also and importantly, from Reland. In fact, he reproduces the entire preface of Reland's De religione Mohammedica. ${ }^{92}$ While also Johannes Nomsz' (1738-1803) Dutch biography of Muhammad (1780) owes much to Reland, ${ }^{93}$ the cultural relativism that Reland's work foreshadows - that is, the idea that different peoples should be 'free to follow their own light, and believe that to be true which thus seems to them'-is fully articulated in the Ideen zur Philosophie der Geschichte der Menscheit (Ideas for the Philosophy of the History of Humankind, 1784-91) of Johann Gottfried Herder (1744-1803). Muhammad, according to Herder, was 'a wondrous combination of everything that nation, tribe, period and environment had to offer: merchant, prophet, preacher, poet, hero and lawgiver, everything according to the Arab style. ${ }^{94}$ From Herder, the view that Muhammad should be understood from within his own milieu ('climate', as Herder would have said) touched Goethe, from whom Thomas Carlyle took it in the later 19th century. It is a view that continues to inspire Arabists and Islamicists to this day.

\section{Bibliography}

\section{Sources}

Abū al-Fidā', Ismāīil b. 'Alī, De vita et rebus gestis Mohammedis, edited and translated by J. Gagnier, Oxford, Sheldon, 1723.

'Āmilī, Bahā' al-Dīn al-, Jāmi'-i 'Abbāsī [online publication], http://shiaonlinelibrary .com (accessed 28 September 2019).

Boulainvilliers, H. de, La vie de Mahomed, London [i.e. Amsterdam], P. Humbert, 1730.

9o Hunt et al., The Book that Changed Europe.

91 Reland had based his engraving on a 'Turkish' oil painting shown to him by the Swedish scholar Michael Eneman, who had visited him in Utrecht. See Vrolijk and Van Leeuwen, Arabic Studies, p. 66.

92 Picart and Bernard, Cérémonies et coutumes religieuses, vol. 5, pp. 81-101. See Brafman, 'Picart, Bernard, Hermes and Muhammad', 150; Hunt et al., The Book that Changed Europe, 261-63.

93 As noted by Richard van Leeuwen in his contribution to this volume.

94 Herder, Ideen, p. 832 (§ IV, 19, IV). 
Catalogus codicum manuscriptorum Arabicorum, Persicorum ... Hadrianus Relandus, Utrecht, Willem Kroon and Gijsbert Tieme van Paddenburg, 1761.

Encyclopédie ou dictionnaire raisonné des sciences, des arts et des métiers, edited by D. Diderot and J. d'Alembert, first published Paris, 1751-1772, http://enccre .academie-sciences.fr/encyclopedie/ (accessed 28 September 2019).

Gagnier, J., La vie de Mahomet, traduite et compilée de l'Alcoran, des Traditions authentiques de la Sonna et des meilleurs Auteurs Arabes, Amsterdam, Wetsteins and Smith, 1732.

Ghazālī, M. al-, K. al-Arba'in fì ușūl al-dīn, Cairo: al-Mațba'a al-'arabiyya, 1344/[1925 or 1926].

Glazemaker, J.H., Mahomets Alkoran, door de heer Du Ryer uit d'Arabische in de Fransche taal gesteld; beneffens een tweevoudige beschryving van Mahomets leven; En een verhaal van des zelfs reis ten Hemel; Gelijk ook zijn samenspraak met de Jood Abdias, first published Amsterdam 1657, reprinted Amsterdam, Jan Rieuwertsz, 1658.

Groot, H. de, Bewys van den waren godsdienst. Mitsgaders zyne andere stichtelyke gedichten, en gezangen, first published 1622, $5^{\text {th }}$ edn., Amsterdam, Evert Visscher, 1728.

Hajarī, Aḥmad b. Qāsim al-, K. Nāṣir al-dīn 'alā al-qawm al-kāfirīn, partially translated by N. Matar, In the Lands of the Christians: Arabic Travel Writing in the Seventeenth Century, New York, Routledge, 2003, pp. 5-44.

Ḥalabī, Ibrāhīm b. Muḥammad al-, Multaqā al-abḥur, edited by W.S. al-Albānī, Damascus, Dār al-Bayrūtī, 1426/2005.

Herbelot, B. d', Bibliothèque orientale, ou dictionnaire universel, contenant généralement tout ce qui regarde la connaissance des Peuples de l'Orient, Paris, Compagnie des Libraires, 1697 .

Herder, J.G., Ideen zur Philosophie der Geschichte der Menschheit, first published 17841791, edited by M. Bollacher, Frankfurt am Main, Deutscher Klassiker Verlag, 1989.

Ibn Kathīr, Ismā̄îl, Al-Bidāya wa-l-nihāya, Beirut, Maktabat al-Macāifi, 1966.

Ibn Ṭufayl, Abū Bakr ibn Muhammad, Hayy b. Yaqzān, translated by J. Bouwmeester, De natuurlyke wysgeer, of het Leven van Hai ebn Jokdan, in het Arabisch beschreven door Abu Jaaphar Ebn Tophail. Voordezen uit de Latynsche overzetting van Eduard Pocok, A.M. in het Nederduitsch vertaald door S.D.B. En nu op nieuws met de Arabische grondtext vergeleken, en met aanmerkingen over eenige duistere plaatzen en spreekwyzen verrykt, Rotterdam, Pieter Van der Veer, 1701.

Kātip Çelebi, Kashf al-zunūn, edited by G. Fluegel, London, Oriental Translation Fund, 1835 .

Lessing, G.E., 'Rettung des Hieronymus Cardanus', first published 1754, in idem, Sämtliche Schriften. Vierter Band, Berlin, Vossische Buchhandlung, 1825, pp. 129-167.

Nasafī, Aḥmad b. Muḥammad al-, Kanz al-daqā’iq, edited by A.D. Sāid Bakdāsh, Medina, Dār al-Sirāj, 1403/1983. 
Nomsz, J., Mohammed, of de hervorming der Arabieren, 2 vols, Amsterdam, D. Klippink, 1780 .

Picart, B. and Bernard, J.-F., Cérémonies et coutumes religieuses de tous les peuples du monde representées par des figures dessinées de la main de Bernard Picard: avec une explication historique, \& quelques dissertations curieuses, 7 vols, Amsterdam, J.F. Bernard, 1723-1737, completed by Supplements, 2 vols, Amsterdam, J.F. Bernard, 1743 .

Pococke, E., Specimen historiæe Arabum. Sive, Gregorii Abul Faraji Malatiensis, de origine \& moribus Arabum succincta narratio, in linguam Latinam conversa, notisque è probatissimis apud ipsos authoribus, fusiùs illustrat, Oxford, H. Hall, 1650.

Prideaux, H., The True Nature of Imposture Fully Displayed in the Life of Mahomet, first published 1697, 8th edn., London,E. Curll, 1723.

Reland, A., Exercitatio philologico-theologica De consensu Mohammedanismi et Judaismi ..., Utrecht, François Halma, 1696.

Reland, A., De religione Mohammedica libri duo, Utrecht, Willem Broedelet, 1705.

Reland, A., 'De jure militari Mohammedanorum', in idem, Dissertationes miscellaneae, Utrecht, Willem Broedelet, 1706-1708, vol. 3, pp. 1-53.

Reland, A., De religione Mohammedica libri duo. Editio altera auctior, Utrecht, Willem Broedelet, 1717.

Reland, A., Verhandeling van de godsdienst der Mahometaanen, als mede van het krygsregt by haar ten tyde van oorlog tegens de christenen gebruykelyk, Utrecht, Willem Broedelet, 1718.

Reland, A., 'Verhandelinge van het Krygs-recht der Mahometaanen', in idem, Verhandeling van de godsdienst der Mahometaanen, Utrecht, Willem Broedelet, 1718, pp. 197-258.

Sale, G., The Koran, Commonly Called the Alcoran of Mohammed, Translated into English immediately from the Original Arabic; with Explanatory Notes, taken from the Most Approved Commentators. To which is prefixed A Preliminary Discourse, London, Printed by C. Ackers for J. Wilcox, 1734 [1733].

Stubbe, H., An Account of the Rise and Progress of Mahometism, London, Luzac \& Co., 1911.

Suyūțī, Jalāl al-Dīn al-, Al-Durr al-manthūr, 8 vols, Beirut, Dār al-Fikr, 1993.

Traité des trois imposteurs, edited and translated by W. Schröder, Hamburg, Felix Meine Verlag, 1992.

Voetius, Disputatio de Mohammedismo, in Selectarum disputationum theologicarum, pars secunda, Utrecht, J. Waesberge, 1655, pp. 66o-683, translated by J. van Amersfoort and W.J. van Asselt, in eisdem, Liever Turks dan Paaps? De visies van Johannes Coccejus, Gisbertus Voetius en Adrianus Relandus op de islam, Zoetermeer, Uitgeverij Boekencentrum, 1997, pp. 59-100. 


\section{Studies}

Ahmed, Sh., 'Satanic verses', in J.D. McAuliffe et al. (eds), Encyclopaedia of the Qur'ān, Leiden, Brill, 2001-20o6, vol. 5, pp. 531b-536a.

Amersfoort, J. van, and W.J. van Asselt, Liever Turks dan Paaps? De visies van Johannes Coccejus, Gisbertus Voetius en Adrianus Relandus op de islam, Zoetermeer, Uitgeverij Boekencentrum, 1997.

Bennett, C., 'Jean Gagnier', in David Thomas and John A. Chesworth (eds), ChristianMuslim Relations: A Bibliographical History; Volume 13: Western Europe (1700-1800), pp. 182-187.

Bevilacqua, A., The Republic of Arabic Letters: Islam and the European Enlightenment, Cambridge, MA, The Belknap Press of Harvard University Press, 2018.

Bouyges, M., Essay de chronologie des œuvres de al-Ghazali (Algazel), Beirut, Imprimerie Catholique, 1959.

Brafman, D., 'Picart, Bernard, Hermes and Muhammad (Not Necessarily in That Order)', in L. Hunt, M.C. Jacob, and W. Mijnhardt (eds), Bernard Picart and the First Global Vision of Religion, Los Angeles, Getty Research Institute, 2010, pp. 139-168.

Bruijn, J.T.P. de, 'The Persian Studies of Adriaan Reland (1676-1718)', in Ch. van Ruymbecke (ed.), Mais « comment peut-on être persan? \& Élements persans en Orient et Occident. Liber amicorum Anette Donckier de Donceel, Leuven, Peeters, 2003, pp. 37-5o.

Daniel, N., Islam and the West: The Making of an Image, first published 196o, revised edition first published 1993, Oxford: Oneworld Publications, 2009.

Dietrich, A., 'Maghnāțīs. 1. The Magnetite and Magnetism', in P.J. Bearman, et al. (eds), Encyclopaedia of Islam, New Edition, Leiden and Boston, Brill, 196o-2005, vol. 5 (1986), pp. 1166b-1168b.

Dimmock, M., Mythologies of the Prophet Muhammad in Early Modern English Culture, Cambridge, Cambridge University Press, 2013.

Ehlert, T., 'Muhammad. 3. The Prophet's Image in Europe and the West, B. The Image in Mediaeval Popular Texts and in Modern European Literature', in P.J. Bearman et al. (eds), Encyclopaedia of Islam, New Edition, Leiden and Boston, Brill, 1960-2005, vol. 7 (1993), pp. 381a-387a.

Fück, J., Die arabischen Studien in Europa bis in den Anfang des 20. Jahrhunderts, Leipzig, Otto Harrassowitz, 1955.

Garcia, H., 'A Hungarian Revolution in Restoration England: Henry Stubbe, Radical Islam, and the Rye House Plot', The Eighteenth Century, vol. 51, no. 1-2, 2010, pp.1-26.

Gelder, M. van, 'The Republic's Renegades: Dutch Converts to Islam in SeventeenthCentury Diplomatic with North Africa', Journal of Early Modern History, vol. 19, no. 2-3, 2015, pp. 175-198.

Gunny, A., The Prophet Muhammad in French and English Literature, 1650 to the Present, Markfield, The Islamic Foundation, 2010. 
Hamilton, A., 'Adriaan Reland: Outstanding Orientalist', in Commissie Geschiedschrijving van de Universiteit Utrecht (eds), Zes keer zestig: 360 jaar universitaire geschiedenis in zes biografië̈n, Utrecht, Afdeling Grafische Zaken, 1996, pp. 23-31.

Hamilton, A., 'From a "Closet at Utrecht": Adriaan Reland and Islam', Nederlands Archief voor Kerkgeschiedenis / Dutch Review of Church History, vol. 78 no. 2, 1998, pp. 243-250.

Hamilton, A., 'The Study of Islam in Early Modern Europe', Archiv für Religionsgeschichte, vol. 3, 2001, pp. 169-182.

Hunt, L., M.C. Jacob. and W. Mijnhardt, The Book that Changed Europe: Picart and Bernard's Religious Ceremonies of the World, Cambridge, MA, Havard University Press, 2010.

Kelsay, J., 'Islam and Christianity in the Works of Gentili, Grotius, and Pufendorf', in S. Hashmi (ed.), Just Wars, Holy Wars, and Jihads: Christian, Jewish, and Muslim Encounters and Exchanges, New York and Oxford, Oxford University Press, 2012, pp. 207-220.

Lange, Ch., Mohammed. Perspectieven op de Profeet, Amsterdam, Amsterdam University Press, 2017.

Matar, N. (ed. and tr.), In the Lands of the Christians: Arabic Travel Writing in the Seventeenth Century, New York and London, Routledge, 2003.

Meier, F., Bemerkungen zur Mohammedverehrung, Teil 1: Die Segenssprechung über Mohammed, edited by B. Radtke and G. Schubert, Leiden, Brill, 2002.

Moore, K.B., The Architecture of the Christian Holy Land: Reception from Late Antiquity through the Renaissance, Cambridge, Cambridge University Press, 2017.

Pellat, Ch., 'Note sure la légende relative au cercuil de Mahomet', Bulletin des Études Arabes, vol. 23, 1945, pp. 112-113.

Pfannmüller, G., Handbuch der Islam-Literatur, Berlin and Leipzig, De Gruyter, 1923.

Reeves, M., Muhammad in Europe: A Thousand Years of Western Myth-Making, New York, New York University Press, 2000.

Rubin, U., 'Pre-Existence and Light: Aspects of the Concept of Nur Muhammad', Israel Oriental Studies, vol. 5, 1975, pp. 62-119.

Schimmel, A., 'Abendländische Islamstudien', in W. Montgomery Watt and A.T. Welch (eds), Der Islam I: Mohammed und die Frühzeit-Islamisches Recht-Religiöses Leben, Stuttgart, Kohlhammer, 1980, pp. 17-38.

Schröder, W., 'Einleitung', in idem (ed. and tr.), Traktat über die drei Betrüger/Traité des trois imposteurs, Hamburg, Felix Meine Verlag, 1992, pp. vii-xliii.

Snouck Hurgronje, Ch., 'Une nouvelle bibliographie de Mohammed', first published 1894, republished in idem, Verspreide geschriften, Bonn-Leipzig, Kurt Schroeder, 1923, vol. 1, pp. 319-362.

Tinniswood, A., Pirates of Barbary: Corsairs, Conquests and Captivity in the 17th-Century Mediterranean, London: Vintage, 2011. 
Tolan, J.V., Saracens: Islam in the Medieval European Imagination, New York, Columbia University Press, 2002.

Tolan, J.V., Faces of Mohammed: Western Perceptions of the Prophet of Islam from the Middle Ages to Today, Princeton, NJ, Princeton University Press, 2019.

Vrolijk, A. and R. van Leeuwen, Arabic Studies in the Netherlands: A Short History in Portraits, 1580-1950, translated by A. Hamilton, Leiden and Boston, Brill, 2014.

Waardenburg, J.D.J., 'Mustashrikūn', in P.J. Bearman et al. (eds), Encyclopaedia of Islam, New Edition, Leiden and Boston, Brill, 196o-2005, vol. 7 (1993), pp. 735b-753b.

Wiegers, G.A., A Learned Muslim Acquaintance of Erpenius and Golius: Ahmad b. Kasim al-Andalusi and Arabic Studies in the Netherlands, Leiden, Dokumentatiebureau Islam-Christendom, 1988. 